\title{
ASSESSMENT OF CONSUMER AWARENESS ON THE CONSUMPTION OF PHYTOESTROGENS IN DIET AND THEIR SUPPLEMENTATION - SURVEY STUDIES
}

\section{OCENA ŚWIADOMOŚCI KONSUMENTÓW DOTYCZĄCA SPOŻYWANIA FITOESTROGENÓW Z DIETĄ ORAZ ICH SUPLEMENTACJI - BADANIA ANKIETOWE}

\author{
${ }^{1}$ Students Scientific Society at the Department of Pharmacognosy and Phytochemistry \\ Studenckie Koło Naukowe przy Katedrze i Zakładzie Farmakognozji i Fitochemii \\ ${ }^{2}$ Department of Pharmacognosy and Phytochemistry, Faculty of Pharmaceutical Sciences in Sosnowiec, \\ Medical University of Silesia, Katowice \\ Katedra i Zakład Farmakognozji i Fitochemii, Wydział Nauk Farmaceutycznych w Sosnowcu, \\ Śląski Uniwersytet Medyczny w Katowicach
}

\begin{abstract}
INTRODUCTION. Phytoestrogens are plant-derived compounds with structural similarity to $17-\beta$-estradiol. They are considered safer substitutes for synthetic drugs, especially in the treatment of menopause related symptoms. They are delivered to the body with diet or as dietary supplements.

AIM OF THE STUDY. The aim of the study was to assess consumer awareness of taking phytoestrogens with diet and supplements, as well as the benefits and risks of such supplementation.

MATERIALS AND METHODS. An original survey form was created for the purpose of the study, 133 questionnaires were completed online, and 100 were distributed to random respondents in the Silesian Voivodship. The vast majority of the respondents $(84.5 \%)$ was represented by women. The study group was diverse in terms of age, education and place of residence.

RESULTS. Most of the respondents (67.4\%) encountered the concept of phytoestrogens. Common plants as: flax, sunflower, pumpkin, European olive and hops were indicated as phytoestrogen main sources. A small group of respondents $(6 \%)$ was convinced of the effectiveness of phytoestrogens and indicated their specific health-promoting activities, $49.4 \%$ said that not every therapy with their use would improve health and $42.9 \%$ declared lack of knowledge in this area. According to the survey outcomes, $16.7 \%$ of respondents unambiguously confirmed beneficial effect of phytoestrogens on menopause symptoms. Half of the respondents had no opinion whether phytoestrogens could be an effective replacement for synthetic drugs based therapies.

CONCLUSIONS. Incomplete knowledge of society regarding the use of phytoestrogens indicates the need for raising awareness of patients/consumers in this area by medical staff and dietitians. Phytoestrogens, when taken responsibly, can have many benefits for human health.
\end{abstract}

Key words: phytoestrogens, diet, menopause, dietary supplements, survey

\section{STRESZCZENIE}

WSTĘP. Fitoestrogeny to związki pozyskiwane z roślin, których działanie opiera się na podobieństwie strukturalnym do 17- $\beta$-estradiolu. Uznawane są za bezpieczniejsze zamienniki leków syntetycznych, szczególnie w terapii dolegliwości związanych z okresem menopauzy. Dostarczane są do organizmu z dietą lub w postaci suplementów.

CEL PRACY. Celem badań była ocena świadomości konsumentów w zakresie spożywania fitoestrogenów wraz z dietą oraz przyjmowania ich w postaci suplementów, a także korzyści i zagrożeń wynikających z ich dostarczania do organizmu człowieka.

(C) National Institute of Public Health - National Institute of Hygiene / Narodowy Instytut Zdrowia Publicznego - Państwowy Zakład Higieny 
MATERIAL I METODY. Na potrzeby badania stworzono autorski formularz ankiety, 133 kwestionariusze zostały wypełnione internetowo, natomiast 100 rozdano przypadkowym respondentom na terenie województwa śląskiego. W badaniu wzięło udział w sumie 233 ankietowanych, z czego zdecydowaną większość (84,5\%) stanowiły kobiety. Badana grupa była zróżnicowana pod względem wieku, wykształcenia oraz miejsca zamieszkania.

WYNIKI. Większość respondentów $(67,4 \%)$ spotkała się z pojęciem fitoestrogeny. Jako ich główne źródła wskazywano najczęściej len zwyczajny, słonecznik zwyczajny, dynię zwyczajną, oliwkę europejską i chmiel zwyczajny. Nieliczna grupa ankietowanych (6\%), przekonana o skuteczności działania fitoestrogenów, wskazywała ich konkretne działania prozdrowotne, 49,4\% stwierdzało, iż nie każda terapia z ich użyciem spowoduje poprawę stanu zdrowia, a 42,9\% deklarowało brak wiedzy w tym zakresie. Spośród badanych $16,7 \%$ jednoznacznie potwierdziło ich korzystny wpływ na objawy menopauzy. Połowa badanych nie miała zdania, co do możliwości skutecznego zastępowania przez fitoestrogeny terapii prowadzonej za pomocą leków syntetycznych.

WNIOSKI. Niepełna wiedza społeczeństwa, dotycząca zastosowania fitoestrogenów w diecie i suplementacji, wskazuje na konieczność jej ciągłego poszerzania wśród pacjentów/konsumentów przez personel medyczny i dietetyków. Fitoestrogeny przyjmowane w sposób odpowiedzialny mogą nieść wiele korzyści dla zdrowia człowieka.

Słowa kluczowe: fitoestrogeny, dieta, menopauza, suplementy diety, ankieta

\section{INTRODUCTION}

Phytoestrogens are a group of plant-derived compounds belonging to polyphenols. Based on the differences in their chemical structure, the following compounds can be distinguished:isoflavones(genistein, daidzein), prenylated flavonoids (8-prenylnaringenin, 6-prenylnaringenin), lignans (secoisolariciresinol, metairesinol), stilbenes (resveratrol) and coumestans (coumestrol) $(1,2)$. Phytoestrogens' chemical structure resembles that of $17-\beta$-estradiol. This structural similarity to the human hormone is responsible for their binding to the $\alpha$ and $\beta$ estrogen receptors (ER $\alpha$ and ER $\beta$ ). The potency of these compounds is lower than that of $17-\beta$-estradiol, and 8-prenylnaringenin is considered the most potent phytoestrogen followed by coumestrol, genistein and daidzein $(2,3)$. Phytoestrogens can have both estrogenic and antiestrogenic effects, and their mechanism of action is tissue-selective. Estradiol acts mainly on ER $\alpha$, while phytoestrogens have a greater affinity for ER $\beta$, which results in their different effects on individual tissues of the body (4). In addition to the genomic mechanisms of phytoestrogens' action, by their effect on the ER, there are also non-genomic ways of interaction of these compounds, e.g. affecting the synthesis and activity of secondary messengers, activation of various protein kinases, affecting the peroxisome proliferator-activated receptors (PPARs), or changing aromatase activity (5). They also affect the cell cycle, apoptosis, they modulate signaling pathways of cells and regulate the level of oxidative stress in the cell (1). Such a variety of mechanisms of action reduces the predictability of the impact of phytoestrogens on the human body. They can show beneficial effects, e.g. alleviate the
WSTĘP

Fitoestrogeny to grupa związków pochodzenia roślinnego należąca do polifenoli. W oparciu o różnice w ich budowie chemicznej można wyróżnić: izoflawony (genisteina, daidzeina), prenylowane flawonoidy (8-prenylnaryngenina, 6-prenylnaryngenina), lignany (sekoizolaricirezinol, metairezinol), stilbeny (resweratrol) i kumestany (kumestrol) $(1,2)$. Fitoestrogeny posiadają strukturę chemiczną zbliżoną do 17- $\beta$-estradiolu. To strukturalne podobieństwo do ludzkiego hormonu jest odpowiedzialne za wiązanie się tych związków z receptorami estrogenowymi $\alpha$ i $\beta$ (ER $\alpha$ i ER $\beta)$. Siła działania tych związków jest mniejsza niż 17- $\beta$-estradiolu, a za najsilniej działający fitoestrogen uznaje się 8-prenylnaryngeninę przed kumestrolem, genisteiną i daidzeiną $(2,3)$. Fitoestrogeny mogą działać zarówno estrogenowo jak i antyestrogenowo, a ich mechanizm działania jest tkankowo selektywny. Estradiol działa głównie na $\mathrm{ER} \alpha$, natomiast fitoestrogeny mają większe powinowactwo do ER $\beta$, z czego wynika ich odmienne działanie na poszczególne tkanki organizmu (4). Oprócz genomowych mechanizmów działania fitoestrogenów, poprzez wpływ na ER, istnieją także niegenomowe drogi oddziaływania tych związków, np. wpływ na syntezę i aktywność wtórnych przekaźników, aktywacja różnych kinaz białkowych, oddziaływanie na receptory aktywowane przez proliferatory peroksysomów (PPAR), czy zmianę aktywności aromatazy (5). Wpływają one również na cykl komórkowy, apoptozę, modulują ścieżki sygnałowe komórek i regulują poziom stresu oksydacyjnego w komórce (1). Taka różnorodność mechanizmów działania zmniejsza przewidywalność wpływu fitoestrogenów na ludzki organizm. Mogą one wykazywać korzystne działania np. łagodzić sympto- 
symptoms of menopause, prevent cardiovascular diseases, regulate glucose metabolism, reduce insulin resistance, improve cognitive functions of the brain, prevent osteoporosis or some cancers $(6,7)$. There are also reports in the literature about the possible negative effects of phytoestrogens, including: fertility problems, feminization in men, the possibility of developing hormone-dependent neoplasms, vaginal bleeding or allergic reactions (7-10). Although side effects occur only occasionally, the precautions are recommended in regard to the type of phytoestrogen taken and the body's response to it. An unbalanced diet and supplementation based on plants rich in phy toestrogens can be detrimental to health. Phytoestrogens, present in the diet, are found in popular plants that provide substances for the production of food products. Such plants are, for example, flax (Linum usitatissimum), Indian sesame (Sesamum indicum), soybean (Glycine max), sunflower (Helianthus annuus), olive (Olea europaea), edible lentil (Lens culinaris) or common hops (Humulus lupulus) (10). Phytoestrogens are also available as dietary supplements and over-the-counter (OTC) medications. Due to the commonly held belief in the safety of using herbal preparations, they are often taken irresponsibly, which results in a lack of therapeutic effect and a possible deterioration of health. Taking into account the complexity of the mechanisms and potency of phytoestrogens, it is not known what their effect on a particular organism might be when the recommended doses are exceeded or when they are used simultaneously with other drugs. Many people, without prior consultation with a physician, pharmacist or dietitian, use supplements containing phytoestrogens as a remedy for their ailments, even though the definition of a dietary supplement clearly emphasizes that it should not be used as a treatment, but can only contribute to the improvement in the functioning of the body (11).

\section{AIM OF THE STUDY}

The main goal of the study was to determine the level of consumers' awareness in the field of dietary phytoestrogens consumption and their supplementation. The goal was achieved by conducting a survey checking consumers' knowledge of the use of phytoestrogens as well as the benefits and risks of taking them.

\section{MATERIAL AND METHODS}

The study was based on a authorial survey prepared for this purpose, in which the diagnostic survey method was used. The survey included questions referring to general knowledge about my menopauzy, zapobiegać chorobom sercowo-naczyniowym, regulować metabolizm glukozy, zmniejszać insulinooporność, poprawiać funkcje poznawcze mózgu, zapobiegać osteoporozie czy niektórym nowotworom $(6,7)$. W literaturze pojawiają się również doniesienia o możliwych negatywnych skutkach stosowania fitoestrogenów m.in.: problemach z płodnością, feminizacją u mężczyzn, możliwością rozwoju nowotworów hormonozależnych, krwawieniach z dróg rodnych lub reakcjach alergicznych (7-10). Mimo że działania niepożądane nie występują często, powinno się zwracać uwagę na rodzaj przyjmowanego fitoestrogenu oraz obserwować odpowiedź organizmu na jego działanie. Niezbilansowana dieta i suplementacja oparta na roślinach bogatych w fitoestrogeny może być niekorzystna dla zdrowia. Fitoestrogeny obecne w diecie znajdują się w popularnych roślinach dostarczających surowców do wytwarzania produktów spożywczych. Takie rośliny to np. len zwyczajny (Linum usitatissimum), sezam indyjski (Sesamum indicum), soja zwyczajna (Glycine max), słonecznik zwyczajny (Helianthus annuus), oliwka europejska (Olea europaea), soczewica jadalna (Lens culinaris) czy chmiel zwyczajny (Humulus lupulus) (10). Fitoestrogeny są również dostępne w postaci suplementów diety i leków dostępnych bez recepty (OTC). Według ogólnie panującego poglądu o bezpieczeństwie stosowania preparatów roślinnych są one często nieodpowiedzialnie przyjmowane, co skutkuje brakiem efektu leczniczego oraz możliwością pogorszenia stanu zdrowia. Ze względu na złożoność mechanizmów i siłę działania fitoestrogenów, nie wiadomo, jaki będzie ich wpływ na konkretny organizm przy przekraczaniu zalecanych dawek lub stosowaniu ich jednocześnie z innymi lekami. Wiele osób, bez uprzedniej konsultacji z lekarzem, farmaceutą czy dietetykiem stosuje suplementy zawierające fitoestrogeny jako remedium na swoje dolegliwości, mimo iż definicja suplementu diety wyraźnie podkreśla, iż nie służy on do leczenia, a jedynie usprawnia funkcjonowanie organizmu (11).

\section{CEL PRACY}

Głównym celem badania było określenie stopnia świadomości konsumentów w zakresie spożywania fitoestrogenów w diecie i ich suplementacji. Cel zrealizowano poprzez wykonanie ankiety sprawdzającej wiedzę konsumentów z zakresu stosowania fitoestrogenów oraz korzyści i zagrożeń wynikających z ich przyjmowania.

\section{MATERIAŁ I METODY}

Badanie przeprowadzono w oparciu o przygotowaną do tego celu autorską ankietę, w której zastosowano metodę sondażu diagnostycznego. Ankieta zawierała 
phytoestrogens, their function, safe use, as well as the benefits and risks of their supplementation. In addition to main questionnaire consisting of nine closed and one semi-open questions, the survey also included a record containing the respondent's data (gender, age, education, place of residence). The survey was created in Google Form and shared on a social media. Additionally, 100 surveys were printed and distributed to random respondents (random selection) in the Silesian Voivodeship, Poland. The study lasted from November 25, 2019 to March 7, 2020. It was attended by 233 respondents (adults), of which $84.5 \%$ were women and $15.5 \%$ men. In order to perform statistical significance tests, the respondents were divided into two age groups: $18-45$ years $(62.2 \%)$ and $>46$ years (37.8\%), following the data regarding the optimal reproductive age in humans and the average age of the menopausal period in women. Most of the respondents had higher education (63.1\%).

Secondary education was declared by $30.5 \%$ of the respondents, vocational $-4.7 \%$, and primary $-1.7 \%$. Most of the respondents came from cities: over 100 thousand inhabitants (46.8\%), 50-100 thousand - 21\%, $10-50$ thousand $-14.2 \%$, less than 10 thousand $7.3 \%$, while $10.7 \%$ of the respondents declared living in rural areas. The survey results were analyzed and developed using Microsoft Excel 2010 and R Core Team 2018 (version 3.5.2). Statistical significance was estimated by applying Pearson's Chi ${ }^{2}$ test for $\mathrm{p}<0.05$.

\section{RESULTS}

Among all the respondents taking part in this study, $67.4 \%$ declared that they know the concept of „phytoestrogens”, while the rest of the respondents were unfamiliar with this term. The survey revealed that $38.6 \%$ of the respondents confirmed the purchase of plant dietary supplements at least once a month, whereas $66.1 \%$ of respondents purchased it once a year. A statistically significant correlation was shown between the age of the respondents and the purchase of a dietary supplement $(\mathrm{p}=0.007)$. Older people ( $>46$ years old) used this type of product more often. Responses to the next question of the survey indicated that the most common sources of phytoestrogens were: flax (42.92\%), sunflower (30.9\%) and pumpkin (28.76\%) (Fig. 1). When asked, whether the therapy using supplements or phytoestrogens can provide health benefits to the body, $49.4 \%$ of respondents stated that not every therapy of this kind would improve health, while $42.9 \%$ admitted to the lack of knowledge in this field. Clear benefits of using this therapy, including the alleviation of menopause symptoms, thyroid disease and hormonal fluctuations, were pointed out by $6 \%$ of respondents. Among the respondents, $1.3 \%$ stated the pytania dotyczące wiedzy ogólnej na temat fitoestrogenów, ich działania, bezpiecznego stosowania oraz korzyści i zagrożeń płynących z ich suplementacji. Oprócz części ankietowej, złożonej z dziewięciu pytań zamkniętych i jednego półotwartego, formularz zawierał metryczkę obejmującą dane respondenta (płeć, wiek, wykształcenie, miejsce zamieszkania). Ankietę utworzono za pomocą Formularza Google i udostępniono na portalu społecznościowym. Część ankiet (100) wydrukowano i rozdano do wypełnienia przypadkowym respondentom (dobór losowy) na terenie województwa śląskiego. Badanie trwało w okresie od 25.11.2019 r. do 07.03.2020 r. Wzięło w nim udział 233 respondentów (osoby pełnoletnie), z czego 84,5\% stanowiły kobiety, natomiast $15,5 \%$ mężczyźni. W celu wykonania testów istotności statystycznej dokonano podziału ankietowanych na dwie grupy wiekowe: 1845 lat $(62,2 \%)$ i $>46$ lat $(37,8 \%)$ kierując się danymi odnośnie optymalnego wieku rozrodczego człowieka i umownego pojawiania się okresu menopauzy u kobiet. Wśród ankietowanych przeważały osoby posiadające wykształcenie wyższe $(63,1 \%)$. Wykształcenie średnie deklarowało 30,5\% respondentów, zawodowe $4,7 \%$, a podstawowe $1,7 \%$ badanych. Większość ankietowanych pochodziła z miast: powyżej 100 tys. mieszkańców (46,8\%), 50-100 tys. - 21\%, 10-50 tys.- 14,2\%, poniżej 10 tys. 7,3\%, natomiast $10,7 \%$ badanych deklarowało zamieszkanie na terenach wiejskich. Wyniki ankiety analizowano i opracowano za pomocą programu Microsoft Excel 2010 oraz programu R Core Team 2018 (wersja 3.5.2). Istotność statystyczną szacowano poprzez zastosowanie testu $\mathrm{Chi}^{2}$ Pearsona dla $\mathrm{p}<0,05$.

\section{WYNIKI}

Znajomość pojęcia „fitoestrogeny” potwierdziło $67,4 \%$ respondentów, reszta nie spotkała się z tym terminem. W grupie ankietowanych $38,6 \%$ zadeklarowało zakup suplementu diety zawierającego związki roślinne przynajmniej raz w miesiącu, a $66,1 \%$ badanych przynajmniej raz $\mathrm{w}$ roku zakupiło taki suplement. Wykazano istotną statystycznie zależność pomiędzy wiekiem respondentów a częstotliwością zakupu takiego suplementu diety $(\mathrm{p}=0,007)$. Osoby starsze $(>46$ lat) częściej używały tego rodzaju produktów. W odpowiedzi na kolejne pytanie ankiety, jako najczęstsze źródła fitoestrogenów respondenci wskazywali: len zwyczajny $(42,92 \%)$, słonecznik zwyczajny $(30,9 \%)$ i dynię zwyczajną (28,76\%) (Ryc.1). Na pytanie, czy terapia z użyciem suplementów zawierających fitoestrogeny może nieść korzyści zdrowotne dla organizmu 49,4\% badanych stwierdzało, iż nie każda taka terapia będzie skutkować poprawą stanu zdrowia, a $42,9 \%$ deklarowało brak wiedzy w tym zakresie. Jednoznacznie korzyści wynikające z ich przyjmowania wskazywało 


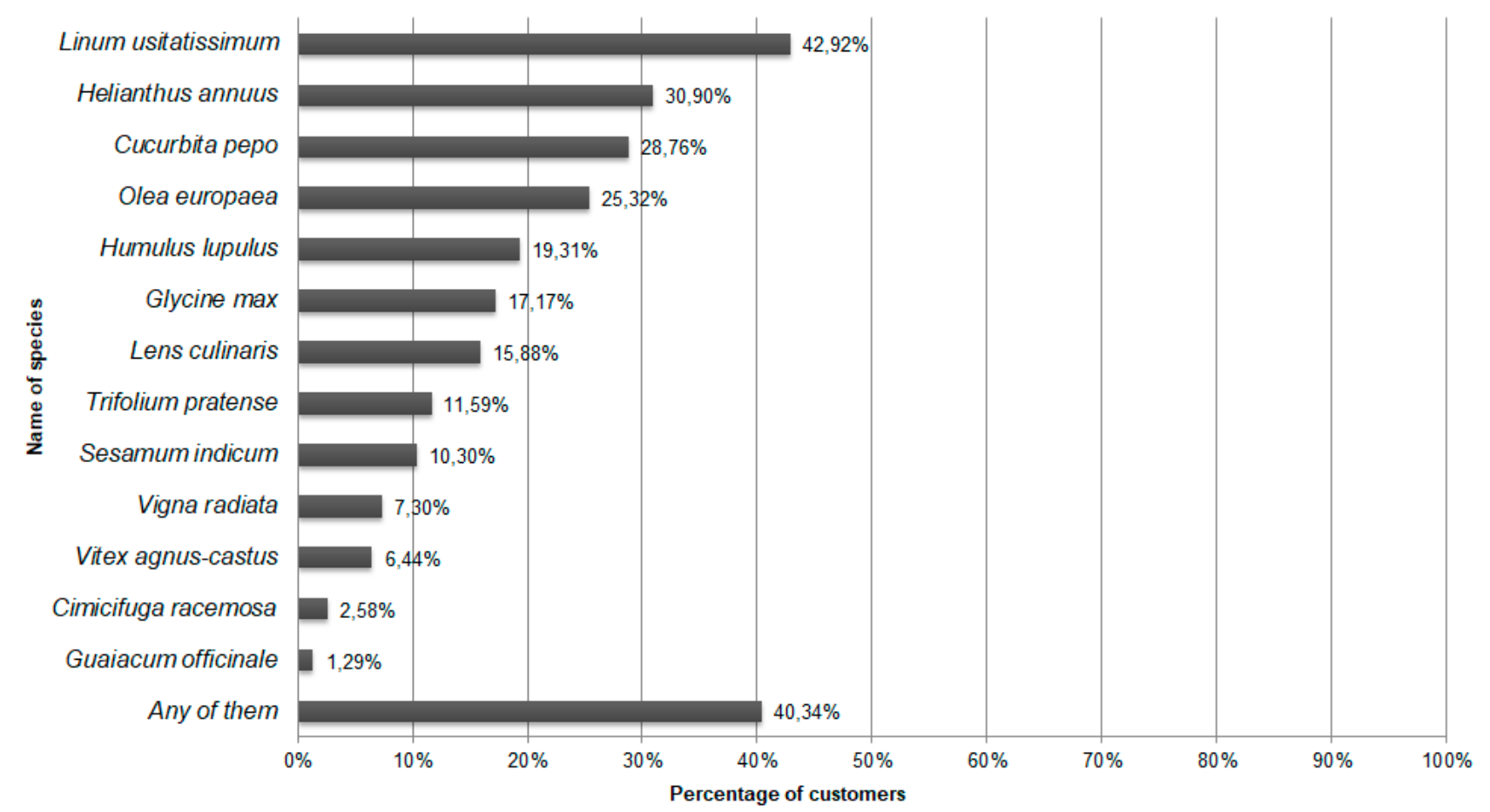

Fig. 1. Percentage of plant species as a sources of phytoestrogens in diet and supplementation

Ryc.1. Udział poszczególnych gatunków roślin jako źródła fitoestrogenów w diecie i suplementacji

possibility of health deterioration as a result of therapy, and $0.4 \%$ considered it absolutely inadvisable.

The survey also included a question about the knowledge of the concept of HRT (hormone replacement therapy) and its use. HRT has been used by $8.2 \%$ of the respondents, $59.2 \%$ of them have heard of it but never used it, while $32.6 \%$ have never heard of it. Among 19 persons who confirmed the use of HRT in the survey, 11 people (which constituted $57.9 \%$ of all the respondents using HRT) were women aged $>46$ years. Taking into account only female respondents, a statistically significant correlation between the age of women and the knowledge of the concept of HRT was observed $(p=0.025)$; women in the older age group ( $>46$ years), at the age which corresponds with the occurrence of menopause, proved to be more familiar with this term (Fig. 2). The respondents were also asked about their opinion on the effects of phytoestrogens on menopause (Fig. 3). Almost half of the respondents (43.8\%) answered the question „I do not know”, $16.7 \%$ clearly confirmed their effectiveness in this regard, $36.9 \%$ stated that not all women would receive measurable benefits as for the alleviation of the symptoms, and $2.6 \%$ denied any effects of phytoestrogens on symptoms. There was no statistically significant correlation between the respondents' level of education and their knowledge of phytoestrogens on the symptoms of menopause ( $p=$ $0.164)$.

The survey also included a question about the frequency of prescribing phytoestrogen supplements
$6 \%$ badanych, wymieniając przy tym konkretne zastosowania np. łagodzenie objawów menopauzy, chorób tarczycy i wahań hormonalnych. Spośród respondentów 1,3\% stwierdzała możliwość pogorszenia się stanu zdrowia po zastosowaniu takiej terapii, a $0,4 \%$, że jest ona absolutnie niewskazana. W ankiecie zapytano także o znajomość pojęcia HTZ (Hormonalna Terapia Zastępcza) oraz o fakt jej stosowania. Wśród ankietowanych $8,2 \%$ stosowało HTZ, 59,2\% słyszało o terapii, ale jej nie stosowało, a 32,6\% nigdy o niej nie słyszało. Spośród 19 osób, które potwierdziły w ankiecie stosowanie HTZ, 11 osób (co stanowiło 57,9\% ankietowanych stosujących HTZ) stanowiły kobiety w wie$\mathrm{ku}>46$ lat. Uwzględniając jedynie respondentów płci żeńskiej, wykazano istotny statystycznie wpływ wieku kobiet, na znajomość pojęcia HTZ $(\mathrm{p}=0,025)$ - kobiety w starszej grupie wiekowej ( $>46$ lat), związanej z występowaniem objawów menopauzy, wykazały się większą znajomością tego pojęcia (Ryc. 2). Ankietowani byli również pytani, czy ich zdaniem fitoestrogeny wpływają korzystnie na objawy menopauzy (Ryc. 3). Prawie połowa badanych $(43,8 \%)$ udzieliła na to pytanie odpowiedzi ,nie wiem”, 16,7\% jednoznacznie potwierdzało ich skuteczność w tym zakresie, $36,9 \%$ stwierdzało, że nie wszystkie kobiety odniosą wymierne korzyści w postaci zaniku objawów w wyniku ich stosowania, a 2,6\% uważało, iż nie wpłyną one na objawy. Nie wykazano istotnego statystycznie wpływu poziomu wykształcenia respondentów na wiedzę z zakresu działania fitoestrogenów na objawy menopauzy $(p=0,164)$. Kwestionariusz zawiera1 


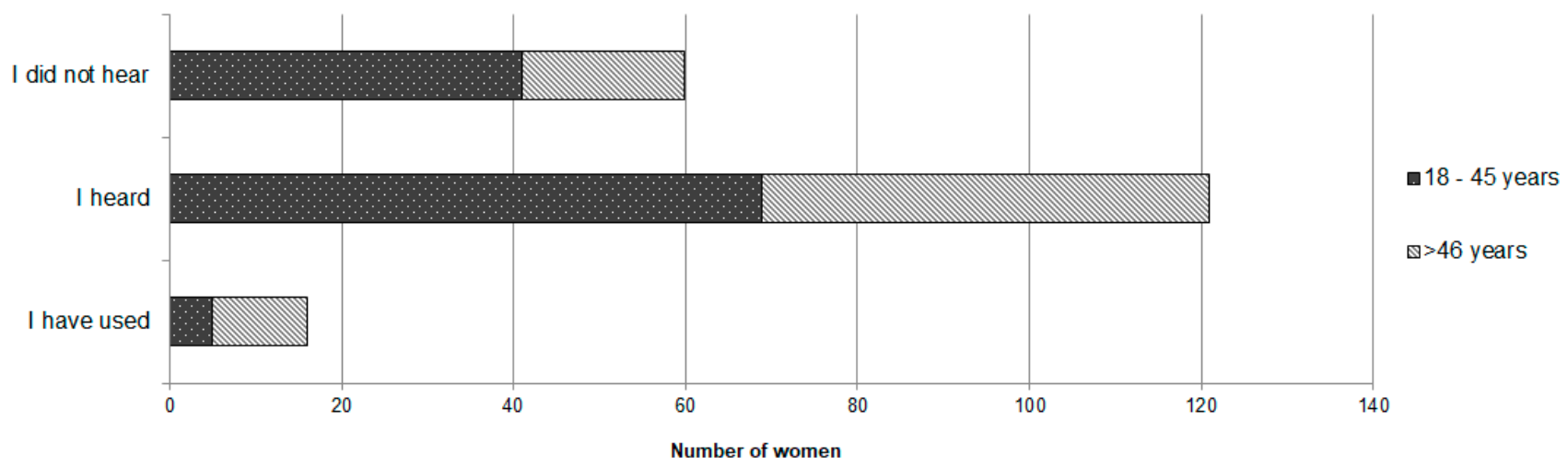

Fig. 2. Knowledge of women in different age on the "HRT" term

Ryc. 2. Znajomość pojęcia „HTZ” u kobiet w różnym wieku

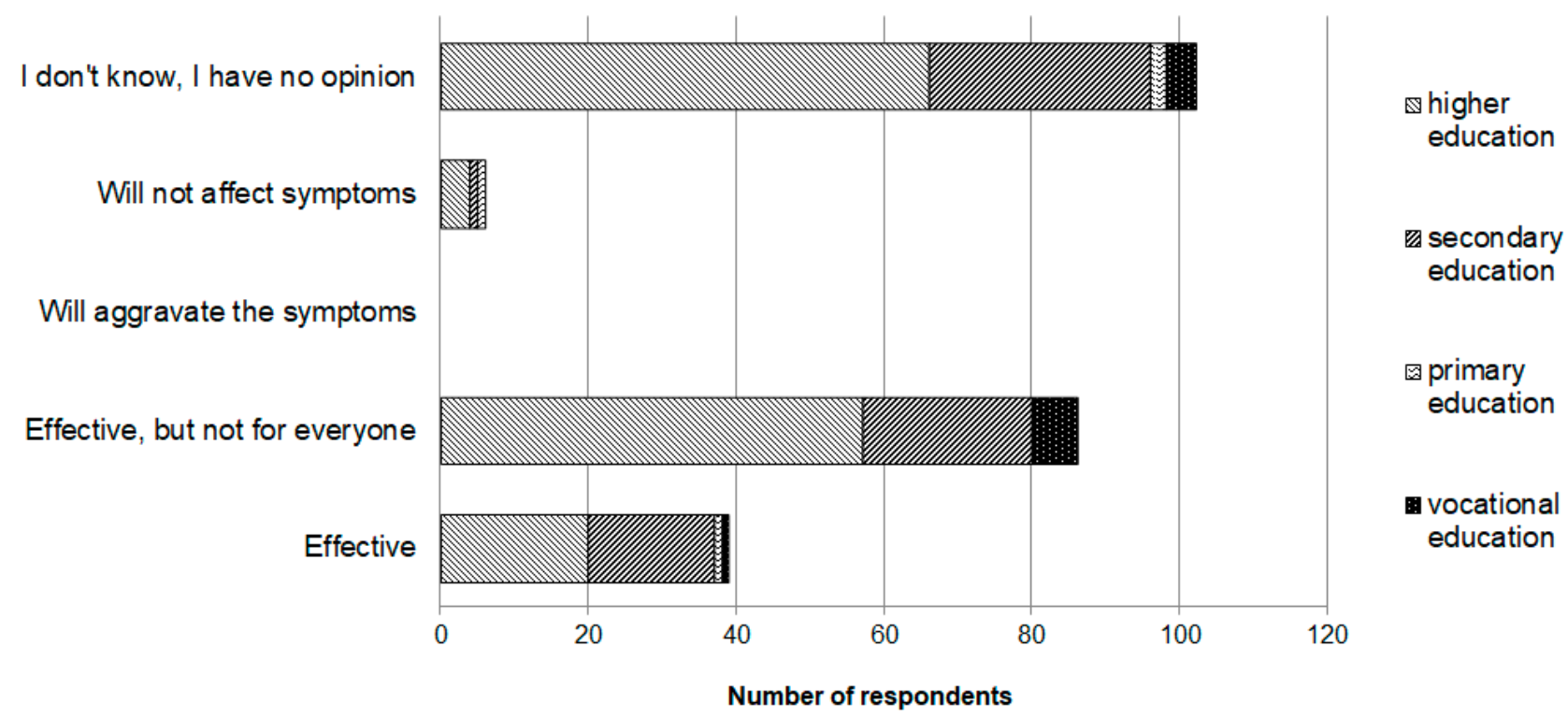

Fig. 3. Assessment of the state of knowledge on phytoestrogens effectiveness in the treatment of menopausal symptoms depending on the respondent's level of education

Ryc. 3. Ocena stanu wiedzy dotyczącej skuteczności fitoestrogenów w terapii objawów menopauzy w zależności od poziomu wykształcania respondenta

by physicians. Therapy with preparations containing these compounds was offered by a physician to $9.9 \%$ of the respondents. When asked if phytoestrogen therapy could be an alternative to synthetic drugs, $50.2 \%$ of the respondents did not have an opinion on this subject, $25.3 \%$ found it equally effective, while $24.5 \%$ of the respondents held the opposite view. There was no correlation between the educational level and the respondents' approach to the possibility of conducting such an alternative therapy $(\mathrm{p}=0.248)$. The questionnaire also included questions referring to the phytoestrogens intake with plants and plant-derived products. One of them concerned the consumption of soybeans and soy-based products (e.g tofu or tempeh). More than a half (57.1\%) of the respondents did not eat soy or its products, $18 \%$ consumed them once a year, $16.7 \%$ once a week, $5.2 \%$ once in 2 weeks and $3 \%$ once także pytanie dotyczące częstości przepisywania preparatów zawierających fitoestrogeny przez lekarzy. Spośród badanych 9,9\% osób potwierdziło, że lekarz proponował im terapię preparatami zawierającymi te związki. Na pytanie, czy terapia fitoestrogenami mogłaby stanowić alternatywę dla leków syntetycznych $50,2 \%$ respondentów nie miało zdania na ten temat, $25,3 \%$ odpowiedziało, że byłaby równie skuteczna, a przeciwnego zdania było $24,5 \%$ ankietowanych. Nie zaobserwowano zależności pomiędzy wykształceniem ankietowanych a podejściem do możliwości prowadzenia takiej alternatywnej terapii $(p=0,248)$. $\mathrm{W}$ zakres ankiety wchodziły również pytania o podaż fitoestrogenów poprzez spożywanie konkretnych roślin i preparatów z nich wytworzonych. Jedno $z$ nich dotyczyło spożycia soi oraz produktów z niej wytworzonych (np. tofu czy tempeh) zawierających fitoestro- 
a week. There was no significant correlation between age and frequency of consumption of soybeans or soybased products $(\mathrm{p}=0.179)$.

Regarding the safety of using hop-based supplements by pregnant women, $2.6 \%$ of the respondents considered it safe, $38.2 \%$ would use such products after consulting a physician, $24 \%$ would not administer them to a pregnant woman, and $35.2 \%$ of respondents did not know if use of the hop-based supplements would be safe.

There was a statistically significant relationship between the age of the respondent and the approach to intake of dietary supplements in pregnancy $(p=0.026)$. Younger people were proved to be much more careful when using this type of supplement.

\section{DISCUSION}

The most common phytoestrogens are lignans and isoflavonoids. A study of phytoestrogen consumption in Spanish women one year before their pregnancy showed that around $65 \%$ of phy toestrogen consumption was covered by lignans, 29\% isoflavonoids and 5\% coumestrol. The source of lignans consumed by women were, among others, vegetables (40\%) and fruit (29\%) (12). The data obtained during the implementation of the EPIC (European Prospective Investigation into Cancer and Nutrition) project show that in many European countries the most frequently consumed group of phytoestrogens were lignans (58.1-67.3\%), and their source was fruit, vegetables, beverages and cereal products (13). The presented study shows that the main sources of phytoestrogens in the diet of the respondents were: flax seeds (the richest source of lignans), sunflower seeds and squash. According to the literature data, these sources of phytoestrogens, which were most often mentioned by respondents, indeed contain a relatively high content of phytoestrogens. Per $100 \mathrm{~g}$ of plant product, flax seeds contain $379 \mathrm{mg}$ of phytoestrogens, soybeans $-103 \mathrm{mg}$, mung beans sprouts $0.5 \mathrm{mg}$, sunflower seeds $-0.2 \mathrm{mg}$, olive oil $0.18 \mathrm{mg}$ and pumpkin $-0.1 \mathrm{mg}$ (10). Therefore, the diet and supplementation of phytoestrogens with the use of these plants should be balanced and properly chosen in order to prevent their increased supply to the body.

Currently, phytoestrogens are being consumed more often in a form of plant-based dietary supplements containing: soybean (Glycine max), hops (Humulus lupulus), red clover (Trifolium pratense), black cohosh (Cimicifuga racemosa) or chasteberry (Vitex agnus-castus). This is related to the increased availability of these preparations on the market. According to the SW Research Market Research and Opinion agency, dietary supplements are used by as many as $72 \%$ of adult Polish residents, including $48 \%$ geny. Wśród respondentów 57,1\% nie spożywało soi i jej produktów, $18 \%$ spożywało je raz w roku, 16,7\% raz w miesiącu, $5,2 \%$ raz na 2 tygodnie a $3 \%$ raz w tygodniu. Nie wykazano istotnej zależności pomiędzy wiekiem a częstotliwością spożycia soi lub produktów $z$ niej wytworzonych $(p=0,179)$. W odniesieniu do bezpieczeństwa stosowania suplementów na bazie chmielu przez kobiety w ciąży, 2,6\% ankietowanych uznało to jednoznacznie za bezpieczne, $38,2 \%$ zastosowałoby taki produkt po zasięgnięciu porady lekarskiej, $24 \%$ nie podałoby go kobiecie $\mathrm{w}$ ciąży, a $35,2 \%$ badanych nie wiedziało, czy jego zastosowanie byłoby bezpieczne. Wykazano istotną statystycznie zależność miedzy wiekiem ankietowanego a opinią na temat podawania takiego rodzaju suplementów diety kobiecie w ciąży $(\mathrm{p}=0,026)$. Osoby młodsze zdecydowanie ostrożniej stosowałyby tego rodzaju suplementy.

\section{DYSKUSJA}

Najbardziej rozpowszechnione fitoestrogeny należą do lignanów i izoflawonoidów. Badanie dotyczące spożycia fitoestrogenów, przeprowadzone w ciągu roku przed zajściem w ciążę u kobiet w Hiszpanii pokazało, że ok. $65 \%$ spożycia fitoestrogenów było pokrywane przez lignany, 29\% izoflawonoidy i 5\% kumestrol. Źródło lignanów dla kobiet stanowiły między innymi: warzywa (40\%) i owoce (29\%) (12). Dane, uzyskane w trakcie realizacji projektu EPIC (European Prospective Investigation into Cancer and Nutrition) wskazują, że najczęściej spożywaną w wielu krajach europejskich grupą fitoestrogenów były lignany $(58,1-$ 67,3\%), a ich źródło stanowiły owoce, warzywa, napoje i produkty zbożowe (13). Z niniejszego badania wynika, że głównymi źródłami fitoestrogenów w diecie wskazywanymi przez ankietowanych były: nasiona lnu zwyczajnego - będące najbogatszym źródłem lignanów, słonecznika zwyczajnego i dyni zwyczajnej. Te najczęściej wskazywane przez respondentów źródła fitoestrogenów zawierają stosunkowo dużą ich zawartość w 100 g produktu roślinnego, odpowiednio: $379 \mathrm{mg}$ - nasiona lnu zwyczajnego, $103 \mathrm{mg}$ - nasiona soi, $0,5 \mathrm{mg}$ - kiełki fasoli mung, $0,2 \mathrm{mg}$ - pestki słonecznika, $0,18 \mathrm{mg}$ - oliwa z oliwek oraz $0,1 \mathrm{mg}-\mathrm{dy}$ nia (10). Dlatego też dieta i suplementacja fitoestrogenów z wykorzystaniem tych roślin powinna być zrównoważona i odpowiednio przemyślana, aby zapobiec wzmożonej ich podaży do organizmu.

Fitoestrogeny są obecnie coraz częściej przyjmowane przez konsumentów w postaci suplementów diety opierających swój skład na roślinach takich jak: soja zwyczajna (Glycine max), chmiel zwyczajny (Humulus lupulus), koniczyna łąkowa (Trifolium pratense), pluskwica groniasta (Cimicifuga racemosa), niepokalanek pospolity (Vitex agnus-castus). Jest to związa- 
using them regularly, but only $17 \%$ of respondents consulted their use with a physician or pharmacist (14). The widespread belief in the safety of herbal preparations leads to their increasing consumption and use in various diseases. This survey indicates that approximately $2 / 3$ of respondents used plant-based dietary supplements at least once a year, and their use was more common among the elderly. A survey conducted in a group of Americans over the age of 60 showed that approximately $21 \%$ used at least one plant supplement, $19 \%$ of which had a potential side effects (15). Phytoestrogens show many potential health benefits but, as this study showed, only few of the respondents confirmed their use in order to achieve particular effects, while almost half of them did not know whether phytoestrogens might bring any health benefits.

Despite the variety of their applications, phytoestrogens are most often used to alleviate the menopause symptoms, and their effects in this area are well-known $(4,7)$. The results obtained during the course of the presented study showed that $17 \%$ of the respondents pointed out the beneficial effect of phytoestrogen on symptoms related to the menopause. According to the results of survey conducted in 1997 by the North American Menopause Society (NAMS), $27 \%$ of women aged $45-60$ used herbal remedies in order to relieve menopause symptoms (16). Many sources indicate that the most popular preparations for this purpose are those based on black cohosh and soybean $(17,18)$. According to a study by Dailey et al. (2003), approximately $72 \%$ of patients reported an improvement in menopause symptoms after taking a dietary supplement containing phytoestrogens. Almost $80 \%$ of the surveyed women expressed a will to widen their knowledge about using herbal products to relieve menopause symptoms. This interest may result from the growing number of reports on the harmful effects of hormone replacement therapy (HRT) (18). The presented study shows that $8.2 \%$ of the respondents used HRT, and 32.6\% never heard of it. Epidemiological data seem to suggest that women are afraid of using HRT due to its side effects (19-21).

The results of the survey presented in this study, as well as other published data, indicates a disadvantageous phenomenon of self-treatment in society. Consumers who use over-the-counter preparations often fail to inform their physician or pharmacist about the purchase of a given supplement or OTC medication. This increases the possibility of drug interactions and health worsening. The research conducted by Dailey et al. 2003, shows that in $35 \%$ of cases physicians were not aware of the usage of the herbal preparations by their patients (18). According to Palinkas and Kabongo (2000), ne ze zwiększającą się dostępnością tych preparatów na rynku. Według agencji Badań Rynku i Opinii SW Research suplementy diety stosuje aż $72 \%$ dorosłych mieszkańców Polski, w tym 48\% regularnie, jednak tylko $17 \%$ ankietowanych konsultuje ich stosowanie z lekarzem lub farmaceutą (14). Istniejące powszechnie przekonanie o bezpieczeństwie preparatów ziołowych powoduje ich rosnące spożycie i wykorzystanie w różnych schorzeniach. Na podstawie badań przedstawionych $\mathrm{w}$ niniejszej pracy wskazano, że ok. 2/3 respondentów przynajmniej raz $\mathrm{w}$ roku używało suplementów diety pochodzenia roślinnego, oraz że były one częściej stosowane przez osoby starsze. Badanie ankietowe przeprowadzone w grupie Amerykanów powyżej 60 . roku życia podaje, że ok. $21 \%$ badanych stosowało przynajmniej jeden suplement pochodzenia roślinnego, z czego u 19\% stwierdzono potencjalną możliwość wystąpienia działań niepożądanych (15). Fitoestrogeny wykazują wiele możliwych korzyści zdrowotnych. Jak pokazało niniejsze badanie, tylko niektórzy respondenci wskazywali na konkretne ich zastosowania, a prawie połowa nie wiedziała, czy mogą one nieść jakiekolwiek zdrowotne korzyści. Pomimo wielu zastosowań fitoestrogeny najczęściej są wykorzystywane do łagodzenia objawów menopauzy - w tym zakresie ich działanie jest dość dobrze poznane $(4,7)$. Wyniki otrzymane w trakcie niniejszego badania pokazały, że korzystny wpływ fitoestrogenów na dolegliwości związane z okresem menopauzy, w sposób jednoznaczny wskazało $17 \%$ ankietowanych. Według wyników ankiety z 1997 r. przeprowadzonej przez North American Menopause Society (NAMS) 27\% kobiet, w wieku 45-60 lat, zażywało preparaty ziołowe w celu złagodzenia objawów menopauzy (16). Wiele źródeł wskazuje, że najpopularniejsze preparaty stosowane w tym celu to te, których skład bazuje na pluskwicy groniastej oraz soi $(17,18)$. Według badań Dailey i wsp. (2003) około 72\% pacjentek zgłosiło złagodzenie objawów menopauzy po zażyciu suplementu diety zawierającego fitoestrogeny. Prawie $80 \%$ badanych kobiet wyraziło chęć wzbogacenia swojej wiedzy $\mathrm{z}$ zakresu stosowania produktów ziołowych w celu złagodzenia objawów menopauzy. Zainteresowanie to możne wynikać z wielu doniesień na temat szkodliwości Hormonalnej Terapii Zastępczej (HTZ) (18). Niniejsze badanie wykazało, że $8,2 \%$ respondentów stosowało HTZ, a 32,6\% nie słyszało o takim rodzaju leczenia. Dane epidemiologiczne pokazują, że kobiety boją się stosowania HTZ, ze względu na jej skutki uboczne (19-21).

Wyniki niniejszej ankiety, jak i inne opublikowane dane, wskazały na pojawianie się w społeczeństwie niekorzystnego zjawiska samoleczenia. Konsumenci, stosujący preparaty dostępne bez recepty, często nie informują o tym swojego lekarza lub farmaceuty, 
$60 \%$ of patients said that they would only inform a physician about self-medication if asked (22). Plant preparations containing phytoestrogens, according to the presented study, were suggested by physicians to $9.9 \%$ of the respondents. Surveys conducted among German physicians treating women with endometrial cancer and menopausal symptoms indicated that as many as $82 \%$ of physicians prescribe non-estrogen therapy to their patients, and $45 \%$ recommend taking phytoestrogens (21).

Incompetent use of phytoestrogens can lead to various unfavorable changes in the body. Although a lot of data emphasize the safety of their use in therapeutic doses, some sources provide information about the possible harmfulness of these compounds. In addition to digestive disorders, such as diarrhea, vomiting, abdominal pain and allergies, some phytoestrogens can cause more serious health effects. Strong phytoestrogens found in common soybean (genistein, daidzein) can disrupt the menstrual cycle and cause contact dermatitis, and taking supplements with chasteberry may result in dizziness, headaches and irritability (23). Black cohosh, rarely mentioned in this study as a source of phytoestrogens, is often used in the USA and considered safe. However, there are reports (case studies) describing its possible hepatotoxicity, increased risk of cardiovasculardiseases related to intake of this plant and drug interactions $(17,24)$. Considering the possible side effects caused by phytoestrogens, it is crucial that qualified health professionals help to educate patients, which would reduce the adverse effects of self-treatment with these preparations.

It is especially important to inform pregnant women which herbal remedies (including those containing phytoestrogens) can be safely used to alleviate stress. When asked about the safety of using dietary supplements based on hops during pregnancy, $2 / 3$ of the respondents did not approve of their use or would use them only after consulting a physicians. This indicates a fairly large responsibility and awareness of people about the importance of being cautious in taking dietary supplements during pregnancy. A survey conducted in California on a group of pregnant women showed that only $13 \%$ of respondents used dietary supplements. A very small proportion of the surveyed women confirmed the use of phytoestrogen supplements during this period (25). Hops-based dietary supplements are also used to alleviate menopausal symptoms and contain a mixture of the flavonoids xanthohumol, isoxanthohumol and 8-prenylnaryngenin. The estrogenic activity of these compounds depends on their metabolism by the human intestinal microflora, the composition of which is not the same for everyone. It causes differences in the rate u którego dokonują zakupu danego suplementu lub leku OTC. Zwiększa to możliwość interakcji lekowych oraz pogorszenia stanu zdrowia. Dailey i wsp. 2003 wskazują, że w 35\% przypadków lekarz nie wiedział o stosowanych przez pacjenta preparatach ziołowych (18). Według Palinkas i Kabongo (2000) 60\% pacjentów stwierdziło, że powie o takim samoleczeniu tylko jeśli zostaną o to zapytani (22). Preparaty roślinne zawierające fitoestrogeny, według przedstawionego badania, były proponowane przez lekarzy $9,9 \%$ respondentów. Ankiety wykonane wśród niemieckich lekarzy leczących kobiety z rakiem endometrium i objawami menopauzy wskazały natomiast, że aż $82 \%$ lekarzy przepisuje swoim pacjentkom nieestrogenową terapię, $w$ tym aż $45 \%$ zaleca przyjmowanie fitoestrogenów (21).

Nieumiejętne stosowanie fitoestrogenów może prowadzić do różnych niekorzystnych zmian w organizmie. Mimo iż wiele danych podkreśla bezpieczeństwo ich stosowania w dawkach terapeutycznych, niektóre źródła podają dane o możliwej szkodliwości tych związków. Oprócz dolegliwości pokarmowych, takich jak biegunka, wymioty, bóle brzucha oraz alergia, niektóre fitoestrogeny mogą wywołać poważniejsze skutki zdrowotne. Silne fitoestrogeny występujące w soi zwyczajnej (genisteina, daidzeina) mogą powodować zaburzenia cyklu menstruacyjnego oraz kontaktowe zapalenie skóry, a przyjmowanie suplementów z niepokalankiem pospolitym może skutkować zawrotami, bólami głowy oraz rozdrażnieniem (23). Pluskwica groniasta, rzadko wskazywana w niniejszym badaniu jako źródło fitoestrogenów, w USA jest często stosowana i uznawana za bezpieczną. Istnieją jednak doniesienia (opisy przypadków) mówiące o jej możliwej hepatotoksyczności, wywoływaniu przez nią chorób sercowo-naczyniowych oraz interakcji lekowych $(17,24)$. Biorąc pod uwagę możliwe działania niepożądane powodowane przez fitoestrogeny ważne jest, aby odpowiednio wykwalifikowani pracownicy służby zdrowia pomagali w edukacji pacjentów, co zmniejszyłoby niekorzystne skutki samoleczenia tymi preparatami.

Szczególnie ważne jest informowanie kobiet w ciąży, jakie środki roślinne (w tym te zawierające fitoestrogeny) mogą bezpiecznie stosować dla złagodzenia stresu. Respondenci zapytani o bezpieczeństwo stosowania $\mathrm{w}$ trakcie ciąży suplementów diety bazujących na chmielu zwyczajnym w $2 / 3$ nie aprobowali ich użycia lub użyliby ich dopiero po konsultacji z lekarzem. Wskazuje to na dość dużą odpowiedzialność i świadomość osób na temat potrzeby zachowania ostrożności w przyjmowaniu suplementów diety w okresie ciąży. Badanie ankietowe przeprowadzone w Kalifornii w grupie kobiet ciężarnych wykazało, że zaledwie 13\% ankietowanych stosowało suplementy diety. Bardzo niewielka część badanych kobiet po- 
of metabolism of these compounds, which reduces the predictability of their action (26). According to the European Medicines Agency (EMA), due to the in vitro antispasmodic effect on the uterus and the lack of date on toxicity, the use of hops and their preparations during pregnancy and lactation should be avoided. Other sources also indicate a continuous lack of data (especially in the case of dietary supplements) on the safety of long-term use of hops-based preparations, in particular 8-prenylnaringenin contained in them, which is a strong ER agonist $(3,27)$.

The plant which is the main source of phytoestrogens both in the diet and in the production of supplements is soy. Soy isoflavonoids (including genistein, the most studied phytoestrogen) are one of the most potent phytoestrogens, and the plant itself is a very popular dietary component around the world. However, the presented study shows that more than half of the respondents did not consume soybeans or soy-based products, such as tofu and tempeh. Other authors also confirm the low popularity of soybean in Poland (28). Soybean popularity is the highest in Asian countries such as Japan, Korea and China, while it is much lower in Western countries: the USA and Poland. Epidemiological data indicate that increased consumption of soybeans and soybean products by Asian populations reduces the incidence of hip fractures (seen in osteoporosis) or cancer incidence (28). The growing level of knowledge about the benefits of soybean phytoestrogens resulted in an increase in their consumption, for instance, in China by $63 \%$ in 2010 2015 (9). All phytoestrogens, including soy-derived, should be used with caution because of their potential side effects. When taking them, attention should be paid to such factors as: ethnic origin of the patient, type of phytoestrogen, its dose, duration of therapy, intestinal flora, contamination of the supplement or the general health condition of the patient. All of them may affect the metabolism of phytoestrogens, which makes it difficult to predict the effects of these compounds on the body (4).

\section{CONCLUSIONS}

Phytoestrogens are consumed with the diet and are taken as dietary supplements and/or over-thecounter medications. These substances can have many beneficial effects on the human body, but only if properly used. The study presented in the article showed that society's knowledge in regard to the use of phytoestrogens is incomplete. Therefore, it is important to raise patients' awareness through broadly understood education conducted by physicians and licensed personnel such as pharmacists and dietitians. It would also be recommended to provide twierdzała zastosowanie w tym okresie suplementów fitoestrogenowych (25). Suplementy diety na bazie chmielu są stosowane również $\mathrm{w}$ łagodzeniu objawów menopauzy i zawierają mieszaninę flawonoidów: ksantohumolu, izoksantohumolu i 8-prenylnaryngeniny. Estrogenowa aktywność tych związków jest zależna od metabolizowania ich przez mikroflorę jelitowa człowieka, której skład nie u każdego jest jednakowy. Powoduje to różnice w szybkości metabolizowania tych związków, co zmniejsza przewidywalność ich działania (26). Według Europejskiej Agencji Leków (EMA) ze względu na przeciwskurczowe działanie in vitro na macicę i brak danych dotyczących toksyczności, należy unikać stosowania chmielu i jego preparatów w okresie ciąży i laktacji. Inne źródła również wskazują na ciągły brak danych (szczególnie w przypadku suplementów diety) dotyczących bezpieczeństwa długoterminowego stosowania preparatów na bazie chmielu, w szczególności zawartej w nich 8-prenylnaryngeniny, będącej silnym agonistą ER $(3,27)$.

Rośliną stanowiącą główne źródło fitoestrogenów zarówno w diecie, jak i produkcji suplementów jest soja. Izoflawonoidy soi (m.in. genisteina, najlepiej przebadany fitoestrogen) są jednymi z najsilniej działających fitoestrogenów, a sama roślina jest bardzo popularnym składnikiem diety na całym świecie. Przedstawione w artykule badanie wskazało jednak, że ponad połowa respondentów nie spożywała soi ani produktów z niej wytworzonych, takich jak np. tofu i tempeh. Niską popularność soi w Polsce potwierdzają również inni autorzy (28). Popularność soi jest największa w krajach azjatyckich, takich jak Japonia, Korea czy Chiny, natomiast zdecydowanie niższa w krajach zachodnich: USA czy Polsce. Dane epidemiologiczne pokazują, że zwiększone spożycie soi i jej produktów przez populacje azjatyckie, zmniejsza częstotliwość występowania pęknięć szyjki kości udowej (występujące w osteoporozie) lub zapadalność na nowotwory (28). Rosnący poziom wiedzy dotyczącej korzyści płynących z przyjmowania fitoestrogenów sojowych spowodował wzrost ich spożycia np. w Chinach o 63\% w latach 2010-2015 (9). Wszystkie fitoestrogeny, łącznie z sojowymi, ze względu na ich potencjalne działania niepożądane muszą być stosowane z należytą ostrożnością. Przyjmując je należy zwracać uwage na czynniki takie jak: pochodzenie etniczne pacjenta, rodzaj fitoestrogenu, wielkość dawki, czas trwania terapii, flora jelitowa, zanieczyszczenie suplementu czy stan ogólny pacjenta. Mogą one wpływać na metabolizm fitoestrogenów, przez co oddziaływanie tych związków na organizm może stać się trudne do przewidzenia (4). 
information on the effects of phytoestrogens through the mass media.

\section{REFERENCES}

1. Hsieh CJ, Hsu YL, Huang YF, Tsai EM. Molecular Mechanisms of Anticancer Effects of Phytoestrogens in Breast Cancer. Curr Protein Pept Sci. 2018; 19(3):323-332.

2. Cos P, De Bruyne T, Apers S, et al. Phytoestrogens: recent developments. Planta Med. 2003; 69(7):58999.

3. Assessment report on Humulus lupulus L., flos EMA/HMPC/418902/2005

4. Szkutnik-Fiedler D, Jędrzejczyk M, Grześkowiak $\mathrm{E}, \mathrm{i}$ in. Rola terapii fitoestrogenowej w łagodzeniu dolegliwości u kobiet po menopauzie. Ginekol. Pol. 2010; 81:929-934.

5. Nynca A, Kraszewska O, Słomczyńska M, $i$ in. Fitoestrogeny . II. Wewnątrzkomórkowy mechanizm działania w układzie rozrodczym samicy. Postępy Biologii Komórki 2007; 34(1):207_222.

6. Desmawati D, Sulastri D. Phytoestrogens and Their Health Effect. Open Access Maced J Med Sci. 2019; 7(3):495-499.

7. Rietjens IMCM, Louisse J, Beekmann K. The potential health effects of dietary phytoestrogens. Br J Pharmacol. 2017; 174:1263-1280.

8. Jargin SV. Soy and phytoestrogens: possible side effects. Ger Med Sci. 2014; 12:1-5. doi: 10.3205/000203.

9. Xiao Y, Zhang S, Tong H, et al. Comprehensive evaluation of the role of soy and isoflavone supplementation in humans and animals over the past two decades. Phytother Res. 2017; 1-11. doi: 10.1002/ptr.5966

10. Gupta C, Prakash D, Gupta S. Phytoestrogens as pharma foods. Adv Food Technol Nutr Sci Open J 2016; 2(1):19-31. doi: 10.17140/ AFTNSOJ-2-127

11. Valavanidis A. Dietary Supplements: Beneficial to Human Health or Just Peace of Mind? A Critical Review on the Issue of Benefit/ Risk of Dietary Supplements. Pharmakeftiki 2016; 28(2):69-92.

12. Carmichael SL, Gonzalez-Feliciano AG, Ma Ch. et al. Estimated dietary phytoestrogen intake and major food sources among women during the year before pregnancy. Nutr J. 2011; 10:105. doi: 10.1186/1475-2891-10-105.

13. Zamora-Ros R, Knaze V, Luja'n-Barroso L, et al. Dietary intakes and food sources of phy toestrogens in the European Prospective Investigation into Cancer and Nutrition (EPIC) 24-hour dietary recall cohort. Eur J Clin Nutr 2012; 1-10. doi:10.1038/ ejcn.2012.36.

14. Lepionka T, Anyżewska A, Łakomy R, i in. Stosowanie suplementów diety a częstotliwość

\section{WNIOSKI}

Fitoestrogeny są spożywane wraz z dietą oraz przyjmowane $\mathrm{w}$ postaci suplementów diety i/lub leków dostępnych bez recepty. Substancje te mogą nieść wiele zdrowotnych korzyści dla człowieka, ale tylko wtedy, jeśli będą odpowiednio stosowane. Przedstawione w artykule badanie pokazało, iż wiedza społeczeństwa w zakresie ich wykorzystania jest niepełna. W związku z tym, ważne jest zwiększanie świadomości pacjentów poprzez szeroko pojętą edukację prowadzoną przez lekarzy oraz uprawnione do tego osoby - farmaceutów i dietetyków. Wskazanym byłoby również przekazywanie informacji dotyczących działania fitoestrogenów za pomocą środków masowego przeka$\mathrm{zu}$.

spożycia wybranych grup produktów przez żołnierzy wojsk specjalnych. Bromat Chem Toksykol 2019; 2:126-131.

15. Marinac JS, Buchinger CL, Godfrey LA, et al. Herbal Products and Dietary Supplements: A Survey of Use, Attitudes, and Knowledge Among Older Adults. J Am Osteopath Assoc. 2007; 107(1):13-23.

16. Kaufert P, Boggs PP, Ettinger B, et al. Women and menopause: Beliefs, attitudes, and behaviors. The North American Menopause Society 1997 Menopause Survey. Menopause 1998; 5:197.

17. Borrelli F, Ernst E. Black cohosh (Cimicifuga racemosa) for menopausal symptoms: a systematic review of its efficacy. Pharmacol Res 2008; 58(1):814. doi: 10.1016/j.phrs.2008.05.008.

18. Dailey RK, Neale AV, Northrup J, et al. Herbal Product Use and Menopause Symptom Relief in Primary Care Patients: A MetroNet Study. J Womens Health (Larchmt) 2003; 12(7):633-641. doi: 10.1089/154099903322404285.

19. Meherishi S, Khandelwal S, Swarankar ML et al. Attitudes and practices of gynecologists in Jaipur toward management of menopause. J Midlife Health. 2010; 1(2): 74. doi:10.4103/09767800.76216.

20. Ahsan M, Mallick AK. The Effect of Soy Isoflavones on the Menopause Rating Scale Scoring in Perimenopausal and Postmenopausal Women: A Pilot Study. J Clin Diagn Res. 2017; 11(9):FC13FC16 doi: 10.7860/JCDR/2017/26034.10654.

21. Hancke K, Foeldi M, Zahradnik HP, et al. Estrogen replacement therapy after endometrial cancer: a survey of physicians' prescribing practice. Climacteric 2010; 13:271-277. doi: 10.3109/13697130903131338.

22. Palinkas LA, Kabongo ML. The use of complementary and alternative medicine by 
primary care patients. A SURF*NET study. J Fam Pract 2000; 49:1121

23. Kargozar R, Azizi H, Salari R. Areview of effective herbal medicines in controlling menopausal symptoms. Electron Physician. 2017; 9(11):58265833. doi:http://dx.doi.org/10.19082/5826.

24. Muqeet Adnan M, Khan M, Hashmi S, et al. Case Report Black Cohosh and Liver Toxicity: Is There a Relationship? Case Rep Gastrointest Med 2014; 2014:860614. doi: 10.1155/2014/860614.

25. Tsui B, Dennehy CE, Tsourounis C. A survey of dietary supplement use during pregnancy at an academic medical center. Am J Obstet Gynecol 2001; 185(2):433-437. doi:10.1067/ mob.2001.116688.

26. Hamm AK, Manter DK, Kirkwood JS, et al. The Effect of Hops (Humulus lupulus L.) Extract Supplementation on Weight Gain, Adiposity and Intestinal Function in Ovariectomized Mice. Nutrients. 2019; 11:3004. doi:10.3390/nu11123004.

27. Minecka A. Zych M, Kaczmarczyk-Sedlak I. 8-Prenylnaringenin from hop (Humulus lupulus
L.) - a panacea for menopause? Herba Pol 2017; 63(4):34-44. doi: 10.1515/hepo-2017-0023.

28. Pabich M, Materska M. Biological Effect of Soy Isoflavones in the Prevention of Civilization Diseases. Nutrients. 2019; 11:1660. doi:10.3390/ nu11071660.

Received: 14.07.2020

Accepted for publication: 15.02.2021

Otrzymano: 14.07.2020 r.

Zaakceptowano do publikacji: 15.02.2021 r.

Address for correspondence:

Adres do korespondencji:

dr hab.n. farm. Maria Zych

Katedra i Zakład Farmakognozji i Fitochemii Wydział Nauk Farmaceutycznych w Sosnowcu Śląski Uniwersytet Medyczny w Katowicach ul. Jagiellońska 4, 41-200 Sosnowiec e-mail:mzych@sum.edu.pl 